\title{
Study on the influence of micro nutrients and growth regulator on the growth and yield of sesame (Sesamum indicum L.) and nutrient availability in coastal saline soil
}

\section{R. SINGARAVEL, D. ELAYARAJAAND K.VISWANATHAN}

Received : 11.03.2016; Revised : 15.04.2016; Accepted : 11.05.2016 MEMBERS OF RESEARCH FORUM:

Corresponding author : R. SINGARAVEL, Department of Soil Science and Agricultural Chemistry, Faculty of Agriculture, Annamalai University, Annamalai Nagar, CHIDAMBARAM (T.N.) INDIA Email: singar_vel@yahoo.co.in

Co-authors :

D. ELAYARAJA AND K.VISWANATHAN, Department of Soil Science and Agricultural Chemistry, Faculty of Agriculture, Annamalai University, Annamalai Nagar, CHIDAMBARAM (T.N.) INDIA

\begin{abstract}
Summary
A pot experiment was conducted in the Department of Soil Science and Agricultural Chemistry, Annamalai University during Feb.-April, 2015. The initial characteristics of experimental soil revealed the saline nature having $\mathrm{pH} 8.02$ and EC $4.26 \mathrm{dS} \mathrm{m}^{-1}$. The available NPK status were low and DTPA extractable $\mathrm{Zn}$ and Mn were below the critical limit. The design of experiment was Completely Randomised Design and the treatments were: $\mathrm{T}_{1}-\mathrm{NPK}\left(35: 23: 23 \mathrm{~kg} \mathrm{~N}: \mathrm{P}_{2} \mathrm{O}_{5}\right.$ : $\left.\mathrm{K}_{2} \mathrm{Oha}^{-1}\right), \mathrm{T}_{2}-\mathrm{NPK}+\mathrm{ZnSO}_{4} @ 25 \mathrm{~kg} \mathrm{ha}^{-1}+\mathrm{MnSO}_{4} @ 5 \mathrm{~kg} \mathrm{ha}^{-1}, \mathrm{~T}_{3}-\mathrm{T}_{2}+\mathrm{FYM} @ 12.5 \mathrm{tha}^{-1}$, $\mathrm{T}_{4}-\mathrm{T}_{2}+$ vermicompost @ $4 \mathrm{tha}^{-1}, \mathrm{~T}_{5}-\mathrm{T}_{2}+$ humic acid @ $20 \mathrm{~kg} \mathrm{ha}^{-1}$. Growth regulator sea weed extract was applied as 0.5 per cent foliar at vegetative and flowering stage for all the treatments except control. The treatments were replicated four times and sesame var TMV- 3 was grown as test crop. The results of the study revealed that among all the treatments, $\mathrm{T}_{5}$, the application of recommended $\mathrm{NPK}+\mathrm{ZnSO}_{4}+\mathrm{MnSO}_{4}$ with humic acid application accounted for a significant increase in growth character, yield components and yield of sesame. This treatment also significantly improved the soil nutrient availability.
\end{abstract}

Key words : Sesame, INM, Growth, Yield, Coastal sandy soil

How to cite this article : Singaravel, R., Elayaraja, D. and Viswanathan, K. (2016). Study on the influence of micro nutrients and growth regulator on the growth and yield of sesame (Sesamum indicum L.) and nutrient availability in coastal saline soil. Asian J. Soil Sci., 11 (1) : 175-178 : DOI : 10.15740/ HAS/AJSS/11.1/175-178. 